
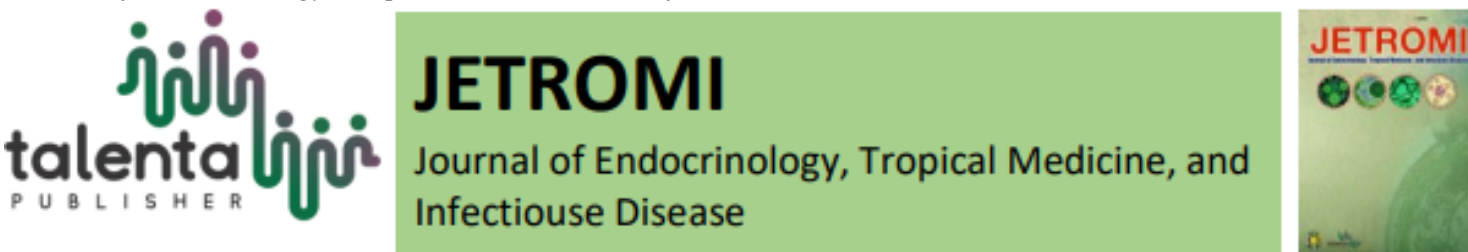

\title{
Clinical Profile of Diabetic Foot Amputation in Hasan Sadikin Hospital, Bandung, Indonesia
}

\author{
Cakra Andhika ${ }^{1}$ and Yoyos Dias Ismiarto ${ }^{1}$ \\ ${ }^{1}$ Department of Orthopaedic and Traumatology, Faculty of Medicine, Padjadjaran University
}

\begin{abstract}
Diabetes mellitus related to foot ulcers is common. Most studies use amputation rates as a measure of foot management in diabetics. The aim of this study was to determine the description of diabetic foot clinical profile at Hasan Sadikin Hospital, Bandung, Indonesia. The study was conducted on diabetic foot who came to Hasan Sadikin Hospital, Bandung from January 2014 to December 2018, retrospectively. There are 243 diabetic foot patients at Hasan Sadikin Hospital in this study. There are 112 males (46.1\%) and 131 females $(53.9 \%)$. There are more patients with the duration of diabetes was more than 10 years than the shorter duration of diabetes. The 51-60 year age group is the group with the largest percentage $(41.6 \%)$. Based on the Wagner classification group, patients with grade 2 Wagner diabetic foot became the most group (28.4\%). Total amputations were 91 patients $(37.5 \%)$. The most diabetic foot management is debridement, which is 110 patients (45.3\%). The most common type of amputation is below knee amputation, which is 45 patients $(49.5 \%)$.
\end{abstract}

Keyword: Amputation, Clinical profile, Diabetes, Diabetic foot, Foot ulcers

\begin{abstract}
Abstrak. Diabetes melitus berhubungan dengan ulkus kaki. Sebagian besar penelitian menggunakan tingkat amputasi sebagai penilaian manajemen kaki diabetes. Tujuan dari penelitian ini adalah untuk mengetahui deskripsi profil klinis kaki diabetes di Rumah Sakit Hasan Sadikin, Bandung, Indonesia. Penelitian ini dilakukan pada kaki diabetes yang datang ke Rumah Sakit Hasan Sadikin, Bandung dari Januari 2014 hingga Desember 2018, secara retrospektif. Ada 243 pasien kaki diabetik di Rumah Sakit Hasan Sadikin dalam penelitian ini. Ada 112 pria (46,1\%) dan 131 wanita (53,9\%). Ada lebih banyak pasien dengan durasi diabetes yang lebih dari 10 tahun daripada durasi diabetes yang lebih pendek. Kelompok usia 51-60 tahun adalah kelompok dengan persentase terbesar (41,6\%). Berdasarkan kelompok klasifikasi Wagner, pasien dengan kaki diabetik Wagner grade 2 menjadi kelompok terbanyak (28,4\%). Total amputasi adalah 91 pasien (37,5\%). Manajemen kaki yang paling diabetes adalah debridement, yaitu 110 pasien (45,3\%). Jenis amputasi yang paling umum adalah amputasi di bawah lutut, yaitu 45 pasien (49,5\%).
\end{abstract}

Kata Kunci: Amputasi, Profil klinis, Diabetes, Kaki Diabetes, Ulkus pedis

Received 21 February 2020 | Revised 22 March 2020 | Accepted 11 May 2020

\footnotetext{
*Corresponding author at: Department of Orthopaedic and Traumatology, Faculty of Medicine, Padjadjaran University
} 


\section{Introduction}

Diabetes mellitus related to foot ulcers is common; as a result of neuropathy, peripheral vascular disease, and infection. Patients with diabetes tend to develop diabetic foot, which may eventually require amputation of the lower limb. Of all people with diabetes mellitus, $15 \%$ will experience foot ulcers throughout their lives. The diabetic foot prevalence is around $4-10 \%$, where the incidence is lower in younger age around $1.5-3.5 \%$ and the highest in the elderly around 5-10\% [1].

Most studies use amputation rates as a measure of foot management in diabetics, although it is known that ulcers alone have reduced quality of life. More than $80 \%$ of amputations are preceded by foot ulcers. A large study in the United Kingdom showed an annual incidence of ulceration of around $2 \%$; increased to $7 \%$ in those who have diabetic neuropathy and can reach $50 \%$ in those who have a history of ulceration. The lifetime risk of a diabetic patient developing a foot ulcer is $25 \%[2]$.

Nearly half of the non-traumatic inferior limb amputations are diabetic patients, and foot ulcers occur in $71-84 \%$ of all inferior limb amputations. In the Caucasian population, 6-43\% of ulcers in the limbs will develop into inferior limb amputations [3].

Early detection and immediate treatment of diabetic foot can reduce complications, and even reduce the prevalence of ulcers by 44-85\% [4]. Data from the National Hospital Discharge Survey (NHDS) shows that ages 45-64 have the highest prevalence of foot ulcers. In addition, it appears that men are more often than women. These ulcers also prolong the length of treatment to 59\% longer than diabetic patients without ulcers, which are 14 days and 8 days [5].

According to several studies in United States of America, patients with foot ulcers who have undergone amputation are around $85 \%$. Based on age group, amputees were as much as $1.6 \%$ in the age range of 18-44 years, 3.4\% in 45-64 years, and the highest is around 3.6\% with age over 65 years. The number of amputations would increase two to four times as the age of patients increased [1].

There are still a few researches on foot ulcer, given the difficulty of gathering data in this diabetic population. Therefore, further studies are still needed regarding ulcers in diabetes [6]. It is known that the risk of ulcers and amputations of inferior limbs is higher in men, in patients with diabetes 10 years or longer, those with uncontrolled blood glucose or having cardiovascular, retinal or renal complications. Given the fact that the majority of the survey population cannot read (63\%), and blood glucose concentration was not controlled in $62 \%$ of the population; as well as the fact that treatment of foot ulcers is poor in most patients by general practitioners [6]. The aim of this study was to determine the description of diabetic foot clinical profile at Hasan Sadikin Hospital, Bandung, Indonesia. 


\section{Methods}

This research was conducted retrospectively. The study was conducted on diabetic foot who came to Hasan Sadikin Hospital, Bandung from January 2014 to December 2018. The grades of diabetic ulcers were assessed based on Wagner criteria. Data were processed descriptively which included gender, age, diabetic foot classification according to Wagner, and management.

\section{Results}

There are 243 diabetic foot patients at Hasan Sadikin Hospital from January 2014 to December 2018. There are 112 males (46.1\%) and 131 females (53.9\%).

Table 1 Baseline Characteristics

\begin{tabular}{lc}
\hline \multicolumn{1}{c}{ Characteristics } & $\mathrm{n}(\%)$ \\
\hline Gender & $112(46.1)$ \\
Male & $131(53.9)$ \\
Female & \\
Diabetic duration & $81(33.3)$ \\
$>10$ years & $54(22.2)$ \\
< 10 years & $108(44.4)$ \\
Unknown & \\
Age group & $21(8.6)$ \\
\40 yo & $69(28.4)$ \\
40 - 50 yo & $101(41.6)$ \\
$51-60$ yo & $52(21.1)$ \\
$>$ 60 yo & \\
Wagner classification & $8(3.3)$ \\
Grade 0 & $23(9.5)$ \\
Grade 1 & $69(28.4)$ \\
Grade 2 & $62(25.2)$ \\
Grade 3 & $55(22.6)$ \\
Grade 4 & $36(14.8)$ \\
Grade 5 & \\
Diabetic foot management & $31(12.7)$ \\
Conservative & $5(2.0)$ \\
Drainage incision & $6(2.5)$ \\
Skin graft & $110(45.3)$ \\
Debridement & $91(37.5)$ \\
Amputation & \\
\hline
\end{tabular}

In this study, there are more patients with the duration of diabetes was more than 10 years than the shorter duration of diabetes. However, the group of patients who did not know the duration of diabetes had the highest percentage. Meanwhile, based on age groups, the 51-60 year age group is the group with the largest percentage, which is $41.6 \%$.

Based on the Wagner classification group, patients with grade 2 Wagner diabetic foot became the most group with $28.4 \%$. The patients with amputations in this study were patients with grade 4 and 5 Wagner diabetic foot. Total amputations were 91 patients (37.5\%). The most diabetic foot management is debridement, which is 110 patients $(45.3 \%)$. 
Table 2 Diabetic foot patients based on amputation type

\begin{tabular}{lc}
\hline \multicolumn{1}{c}{ Amputation type } & $\mathrm{n}(\%)$ \\
\hline Ray amputation & $40(43.9)$ \\
Below knee amputation & $45(49.5)$ \\
Transfemoral amputation & $4(4.4)$ \\
Syme amputation & $2(2.2)$ \\
Total & $91(100)$ \\
\hline
\end{tabular}

Based on the type of amputation, all grade 4 Wagner diabetic foot patients were amputated with a ray amputation type, as many as 40 patients (43.9). Other types of amputations, such as below knee amputation, transfemoral amputation, and syme amputation are performed on grade 5 Wagner diabetic foot patients. The most common type is below knee amputation, which is 45 patients (49.5).

\section{Discussion}

The risk of ulcers and amputation of the inferior limb is higher in men [4]. Based on this research, it was found that women had a higher incidence. This could be due to diabetes duration 10 years or longer, uncontrolled blood glucose levels, and poor foot ulcers management in most patients [6].Diabetes mellitus is classified into four types, which are type 1, type 2, gestational diabetes, and other type of diabetes. More than $90 \%$ of diabetes mellitus are type two diabetes mellitus [7]. Women are more likely to develop diabetes than men [8]. Within the diabetic population, the incidence of foot ulcer has been reported to be 4-10\% [9]. It is known that the risk of ulcers and amputations of inferior limbs is higher in patients with 10 years or longer diabetes duration [6]. It also appears that some of patients with diabetic foot do not have a history of diabetes before. More than half of all non-traumatic lower limb amputations are due to diabetes [10]. A longer duration of ulcer was strongly associated with lower limb amputations. Foot ulcer longer than one month increased amputation risk ten folds [11]. In addition, it has been estimated that every 20 seconds a lower limb is amputated due to diabetic complications. Every year, 5\% of diabetic patients develop foot ulcers and $1 \%$ require amputation [12].

Data from the National Hospital Discharge Survey (NHDS) shows that ages 45-64 have the highest prevalence of foot ulcers [1]. Based on Ahmed et al, the majority of diabetic foot are found at the age of 40-60 years [4]. This study shows that the age of 40-60 years has a higher risk for diabetic foot. Estimated prevalence is $4-10 \%$, where the incidence is lower at a young age (1.5-3.5\%) and the highest at advanced age (5-10\%). We also found that the number of amputations increase two to four times as the patients' age increased [1].

Other study found that most diabetic foot patients come to the hospital with grade 2 to 4 Wagner diabetic foot [4]. In this study, we found that grade 2 and 5 Wagner diabetic foot are the most patients' group based on Wagner classification. The prevalence is increasing year by year. From 
research conducted in India, most patients have grade 4 Wagner diabetic foot, followed by grade 2 and grade 3 [13].

We found that debridement of wounds and amputations are most commonly performed. Insulin administration for blood glucose regulation is given in type 2 diabetes patients with infections. From previous studies, $28 \%$ of cases were underwent the debridement and $48 \%$ cases were amputated [4]. Other studies found that the most frequent procedure was debridement (41\%) followed by amputations (35\%) [13]. There are many different levels of amputation, so that the surgeon should consider patient-specific factors, such as functional status and level of social support [14].

There are many patients who underwent below knee amputation and ray amputation to treat diabetic foot. From research conducted in Pakistan, 22.9\% below knee amputation was obtained and ray amputation was $66.6 \%$ [4]. It was found that many patients with grade 4 underwent ray amputation and for grade 5 underwent below knee amputation. Other studies found that below knee amputation is one of the most frequent amputation procedure [15].

\section{Conclusion}

From the results of the study, it can be concluded that in general the description of diabetic foot in Hasan Sadikin Hospital handled by the Department of Internal Medicine and the Department of Orthopedics and Traumatology: all patients with type 2 diabetes mellitus; most patients are woman; most patients are with grade 2 Wagner diabetic foot, the most frequent treatments are debridement and amputation surgery with the most types of surgery are ray amputation and below knee amputation.

\section{Conflict of Interests}

The authors declare that there is no conflict of interest regarding the publication of this paper.

\section{References}

[1] Katsilambros N, Dounis E, Makrilakis K, Tentolouris N, Tsapoga P. Atlas of the diabetic foot. USA: John Wiley \& Sons. 2011.

[2] Brownlee M, Aiello LP, Cooper ME, Vinik AI, Plutzky J, Boulton AJM. Complication of diabetes mellitus. In Melmed S, Polonsky K, Larsen R, Kronenberg H. Williams Textbook of Endocrinology $13^{\text {th }}$ edition. Philadelphia: Elseviers pp.1484-1581. 2016

[3] Kahn CR, Weir GC, King GL. Joslin's Diabetes Mellitus $14^{\text {th }}$ edition. Boston: Lippincott Williams \& Wilkin pp.1111-1120. 2005

[4] Muqim RU, Ahmed M, Griffin S. Evaluation and management of diabetic foot according to Wagner's classification, a study of 100 cases. J Ayub Med Coll Abbottabad.vol.15, no.3 pp:39-42. 2003

[5] Goettl K, Pearson C, Botros M. Diabetic foot ulcers. Wound Care Canad vol.6, no.2. 2008 
[6] Leese GP, Stang D, Mcknight JA. Scottish Diabetes Foot Action Group. A national strategic approach to diabetic foot disease in Scotland: changing a culture. The British Journal of Diabetes \& Vascular Disease vol.11n no.2, pp.69-73. 2011

[7] Decroli E. Diabetes Melitus Tipe 2. Padang: Pusat Penerbitan Bagian Ilmu Penyakit Dalam Fakultas Kedokteran Universitas Andalas; 2019.

[8] Decroli E, Kam A, Dillasamola D. The percentage of depressive symptoms in patients with type 2 diabetes mellitus in M Djamil General Hospital Padang, Indonesia. Journal of Research in Pharmacy vol.23, no.2 pp:292-7. 2019

[9] Lindarto D. Holistic management of diabetic foot. IOP Conference Series: Earth and Environment Science pp:125:1-7. 2018

[10] Atosona A, Larbie C. Prevalence and determinants of diabetic foot ulcers and lower extremity amputations in three selected tertiary hospitals in Ghana. Hindawi Journal of Diabetes Research pp:1-9. 2019

[11] Ugwu E, Adeleye O, Gezawa I, Okpe I, Enamino M, Ezeani I. Predictors of lower extremity amputation in patients with diabetic foot ulcer: findings from MEDFUN, a multi-center observational study. Journal of Foot and Ankle Research pp:12, no. 34, pp:1-8. 2019

[12] Marzoq A, Shiaa N, Zaboon R, Baghlany Q, Alabbood MH. Assessment of the outcome of diabetic foot ulcers in Basrah, Southern Iraq: a cohort study. Int J Diabetes Metab.vol.25, pp:33-38. 2019

[13] Mehraj M. A review of Wagner classification and current concepts in management of diabetic foot. International Journal of Orthopaedics Sciences vol.4, no.1, pp:933-935. 2018

[14] Core MAD, Ahn J, Lewis RB, Raspovic KM, Laili TAJ, Wukich DK. The evaluation and treatment of diabetic foot ulcers and diabetic foot infections. Foot and Ankle Orthopaedics vol.3, no.3, pp:1-11. 2018

[15] Ashokkumar D, Vinothkumar S, Heber A. Outcome of patients undergoing amputation for diabetic foot ulcer. International Surgery Journal vol.6, no.1, pp.88-91. 2019 